\title{
SURVEY PERILAKU MAHASISWA DALAM MENGGUNAKAN KOMPUTER PORTABEL
}

\author{
Anita Juraida \\ Program Studi Teknik Industri, Fakultas Teknik \\ Universitas Widyatama \\ anita.juraida@widyatama.ac.id
}

\begin{abstract}
Abstrak
Penggunaan komputer portabel menjadi bagian yang tidak terpisahkan dalam kehidupan sehari-hari mahasiswa. Khususnya komputer jinjing dan tablet yang memudahkan mahasiswa dalam melakukan pekerjaan. Mahasiswa seringkali menggunakan komputer portabel di tempat-tempat umum karena sifat yang ringan dan mudah dibawa kemana saja. Tujuan penelitian ini adalah untuk menganalisis perilaku mahasiswa dalam menggunakan perangkat komputer portabel. Pengukuran dilaksanakan untuk mengetahui durasi penggunaan, lama kepemilikan, perilaku penggunaan di tempat umum, serta keluhan atau ketidaknyamanan saat menggunakan komputer jinjing dan tablet. Hasil survei membuktikan 92 persen mahasiswa menggunakan komputer portabel di tempat-tempat umum, khususnya tempat makan. Sebagian besar mahasiswa menggunakan komputer jinjing untuk melakukan pekerjaan office (word, excel, power point), sedangkan tablet digunakan untuk mengakses media sosial. Posisi duduk dengan komputer portabel di atas meja menjadi posisi yang paling sering dilakukan oleh mahasiswa. Area tubuh yang mengalami keluhan tertinggi dalam menggunakan komputer jinjing dan tablet yaitu bagian leher. Hasil dari penelitian ini dapat memberikan informasi mengenai perilaku mahasiswa dalam menggunakan komputer portabel.
\end{abstract}

Kata kunci: komputer jinjing, tablet, kelelahan use it in public places. The purposes of this research are to analyze behaviour of students in using a portable computer device. Measurements carried out to determine the duration of use, length of ownership, usage behavior in public places, and feel discomfort when using portable computers and tablets.Based on the survey result, 92 percent of college students use portable computers in public places, especially in restaurants. Most students use laptops to do office work (word, excel, power point), whereas tablets are used to access social media. The position of sitting with portable computer on a table into a position that is most often done by the students. The highest perceived complaints of students in using a portable computer and a tablet that is part of the neck. The results of this study can give information about the behavior of students in the use of portable computers.

Keywords: fatigue, netbook, tablet

\section{Pendahuluan}

Saat ini penggunaan komputer telah berubah seiring beragamnya jenis komputer. Salah satunya adalah komputer portabel, yaitu komputer ringan dan mudah dibawa kemana-kemana. Asosiasi Pengusaha Komputer Indonesia (Apkomindo) pada tahun 2012 menyatakan bahwa saat ini 60 persen dari pangsa pasar komputer didominasi oleh perangkat komputer jinjing dan komputer tablet sekitar 10 sampai 15 persen.

Menurut Apkomindo (2012), adanya varian dari komputer jinjing yang murah membuat penjualan komputer jinjing didominasi oleh mahasiswa. Di lingkungan mahasiswa Indonesia telah terdapat penelitian mengenai penggunaan komputer jinjing dengan dampak kesehatan yang ditimbulkannya. 
Hasil penelitian menunjukkan 97\% mahasiswa mengalami keluhan kesehatan akibat penggunaan komputer jinjing. Bagian tubuh yang banyak dikeluhkan antara lain leher, mata, bahu, punggung bagian atas dan pergelangan tangan (Zulkarnaen, 2012).

Selain itu, mahasiswa juga sering melaksanakan tugas dengan komputer portabel di tempat-tempat umum. Tempat tersebut jauh dari kondisi ideal, misalnya di ruang tunggu, cafe, mobil, pesawat, kereta, dan bandara. Kondisi tersebut memungkinkan adanya variasi sikap kerja selama penggunaan komputer portabel (Gold dkk, 2012; Asundi, 2012; Kraker, 2009).

Saat penggunaan komputer portabel di tempat umum, beragam posisi dilakukan untuk menyesuaikan terhadap tempat yang digunakan. Gold dkk (2012) menyatakan posisi yang sering dilakukan saat menggunakan komputer jinjing di berbagai tempat, terdiri dari duduk dengan komputer jinjing di atas meja, duduk dengan lutut dan paha sebagai alas komputer jinjing, berbaring, dan tidur terlungkup. Pendapat yang hampir sama dinyatakan oleh Young dkk (2012), bahwa posisi yang sering dilakukan saat menggunakan tablet di berbagai tempat adalah memposisikan tablet di atas meja dengan menggunakan pelindung tablet dan memposisikan tablet di atas paha sebagai alas.

Menurut Health Council of the Netherlands (2012), saat ini penggunaan komputer mengalami perubahan, yaitu perubahan pada perangkat komputer (penggunaan peralatan yang berbeda, seperti komputer jinjing dan tablet) dan perubahan tempat kerja. Penelitian yang membahas tentang perubahan pada perangkat komputer misalnya penelitian Young dkk (2013), menjelaskan bahwa penggunaan tablet menyebabkan sikap pergelangan tangan yang canggung dan berisiko lebih besar terkena gejala muskuloskeletal dibandingkan perangkat komputer lainnya. Sedangkan penelitian yang membahas tentang perubahan tempat kerja seperti penelitian Gold dkk (2012), menyatakan bahwa saat menggunakan komputer jinjing di lingkungan nontradisional (duduk di sofa), potensi cidera akan meningkat, baik di bagian tubuh leher, bahu, siku atau pergelangan tangan.

Untuk itu diperlukan suatu penelitian yang lebih komprehensif membahas fenomena perilaku penggunaan komputer portabel serta akibat yang ditimbukannya. Penelitian ini akan mensurvey perilaku mahasiswa dalam menggunakan komputer portabel (komputer jinjing dan tablet) yang berkaitan dengan risiko terjadinya ketidaknyamanan di area tubuh.

\section{KAJIAN LiteratUR}

Kata komputer menurut istilah berasal dari bahasa latin "computere" dan bahasa Inggris "to compute" yang berarti menghitung. Menurut Hamacher dkk (2001), komputer adalah mesin penghitung elektronik yang cepat dan dapat menerima informasi input digital, kemudian memprosesnya sesuai dengan program yang tersimpan di memorinya, dan menghasilkan output berupa informasi.

\section{II.1 Jenis-jenis Komputer}

Komputer secara umum dapat diklasifikasikan berdasarkan ukuran. Jenis-jenis komputer antara lain (Hamacher dkk (2001):

a. Komputer meja (desktop), adalah jenis komputer yang dirancang untuk diletakkan dan digunakan di atas meja rumah atau kantor. Contoh komputer meja dapat dilihat pada Gambar 1.

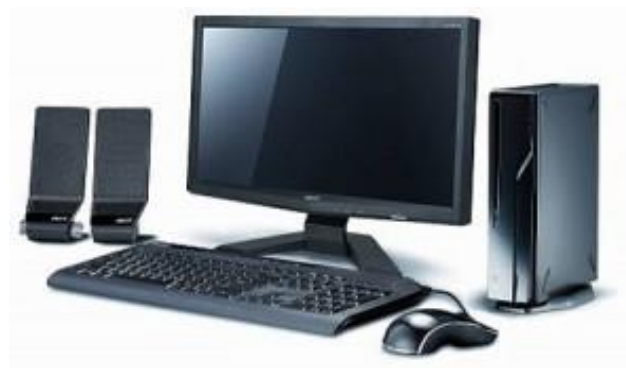

Gambar 1. Komputer meja (Sumber: btechnologies.com)

b. Komputer portabel (mudah dibawa ke manamana) adalah komputer yang memiliki ukuran yang lebih kecil dari komputer meja. Bagianbagian dari komputer portabel dirangkai menjadi satu bagian saja, sehingga mudah dibawa kemana-mana. Komputer ini ditujukan bagi pemakai yang sering bertugas di lapangan yang jauh dari kantornya. Contoh komputer portabel dapat dilihat pada Gambar 2. 


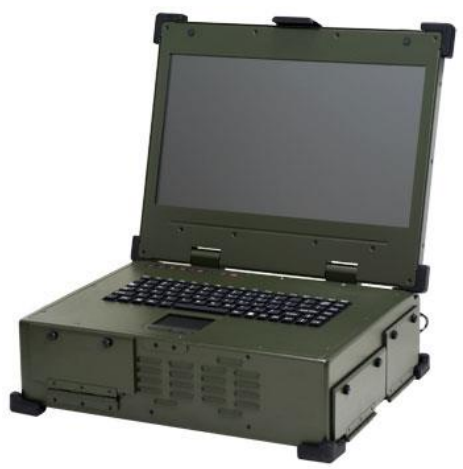

Gambar 1. Komputer portabel (Sumber: ipctechnology.com)

Saat ini, penggunaan nama komputer portabel berubah seiring beragamnya jenis komputer yang ada. Sebuah komputer portabel diartikan sebagai komputer pribadi yang memiliki ukuran yang kecil dan dirancang untuk mudah dibawa kemana-mana.

c. Komputer genggam, adalah komputer yang ukurannya sangat kecil sehingga dapat digenggam. Komputer ini sering disebut handheld computer. Komputer ini tidak memerlukan aliran listrik, melainkan baterai kecil biasa (ukuran AA). Kelemahan dari komputer ini adalah layar dan keyboard yang terlalu kecil, sehingga menyulitkan pamakai. Contoh komputer genggam dapat dilihat pada Gambar 3.

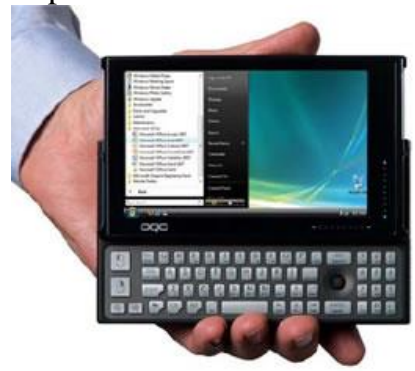

Gambar 2. Komputer genggam (Sumber: ipctechnology.com)

\section{II.2 Komputer Portabel}

Komputer portabel adalah komputer ringan dan mudah dibawa kemana-kemana. Terdapat jenis komputer portabel, seperti komputer jinjing dan tablet, namun terdapat juga perangkat genggam yang dapat digunakan sebagai komputer portabel yang dapat dilihat pada Gambar II.4

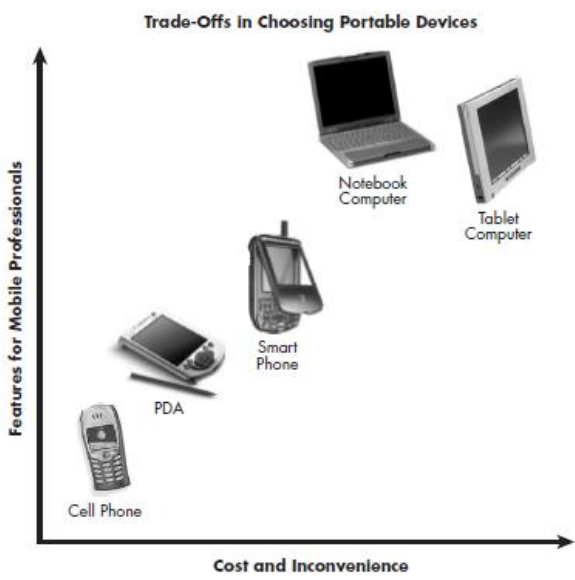

Gambar 3. Macam-macam komputer portabel (Sumber: portablecomputingdevices.com)

Pada Gambar 4 dapat dilihat bahwa komputer jinjing dan tablet hampir berada di kuadran yang sama. Kedua komputer tersebut memiliki fitur kemudahan dibawa kemana-mana yang hampir mirip, namun memiliki perbedaan pada harga dan tingkat kenyamanan. Komputer jinjing adalah komputer yang berukuran relatif kecil dan ringan yang memiliki fungsi yang sama dengan komputer meja. Komponen yang terdapat di dalamnya sama persis dengan komputer meja, namun komputer jinjing memiliki komponen pendukung yang didesain secara khusus untuk mengakomodasi sifat portabel, yaitu ukuran yang kecil sekitar 10 inci hingga 17 inci, lebih ringan, dan lebih hemat daya.

Berbeda dengan komputer jinjing, jenis komputer portabel selanjutnya adalah Personal Computer Tablet (PC Tablet) atau yang dikenal dengan nama tablet. Tablet merupakan komputer yang seluruh bagiannya berupa layar sentuh datar. Ciri utama pada sebuah tablet adalah penggunaan layar sebagai keyboard yang menggunakan teknologi layar sentuh dengan menggunakan ujung jari tangan maupun pena digital. Contoh komputer jinjing dan tablet dapat dilihat pada Gambar 5 dan 6. 


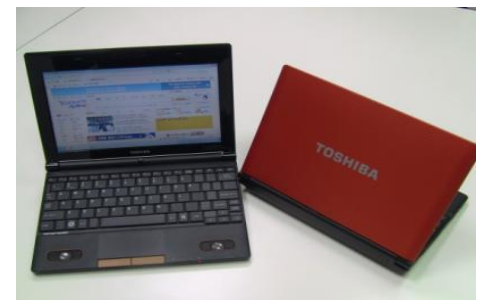

Gambar 4. Komputer jinjing (Sumber: Netbooknews.com)

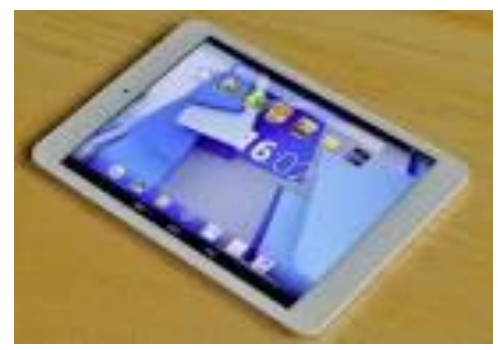

Gambar 5. Komputer tablet (Sumber: Netbooknews.com)

\section{II.3 Gangguan Muskuloskeletal}

Gangguan muskuloskeletal adalah gangguan atau kelainan pada jaringan lunak (seperti otot, tendon, ligamen, sendi, dan tulang rawan) dan pada sistem saraf (OSHA, 2000). Gangguan muskuloskeletal ini diterjemahkan sebagai kerusakan trauma kumulatif. Penyakit ini terjadi akibat proses penumpukan cidera atau kerusakan kecil pada sistem muskuloskeletal akibat trauma berulang yang setiap kalinya tidak dapat sembuh sempurna, sehingga membentuk kerusakan cukup besar untuk menimbulkan rasa sakit.

\section{II.4 Keterkaitan Komputer dengan Gangguan Muskuloskeletal}

Pada pekerjaan yang berkaitan dengan penggunaan komputer, terdapat faktor risiko atau kondisi-kondisi tertentu yang berkontribusi terhadap terjadinya gangguan muskuloskeletal, terutama apabila pengguna komputer dalam jangka waktu yang lama. Menurut Worksafe (2010), kondisi tersebut, antara lain :

1. Bekerja dalam jangka waktu lama tanpa istirahat.
2. Mengeluarkan tenaga saat menekan keyboard atau saat memegang perangkat pendukung seperti mouse.

3. Bekerja dengan postur leher, bahu, siku, pergelangan tangan dan punggung pada sikap kerja canggung.

4. Bertahan pada posisi tubuh yang sama dalam waktu lama tanpa melakukan pergerakan kecil, seperti duduk atau memegang mouse.

5. Penekanan secara terus-menerus pada pergelangan tangan, lengan dan siku terhadap tepi meja kerja atau kaki bagian belakang terhadap bagian depan kursi kerja

\section{III.PENGOLAHAN DATA}

Survei lapangan dilakukan untuk mengidentifikasikan perilaku mahasiswa dalam menggunakan komputer portabel (komputer jinjing dan tablet). Sebanyak 100 kuesioner diberikan kepada partisipan secara random. Seluruh partisipan merupakan mahasiswa berusia 20-25 tahun. Hal ini mengacu pada survei Asosiasi Penyelenggara Jasa Internet Indonesia (2012) yang menyatakan bahwa rentang umur tersebut merupakan pengguna tertinggi internet maupun perangkat teknologi (APJII, 2012). Seluruh partisipan terbiasa menggunakan komputer portabel minimal dua jam per sekali pemakaian (Dowler dkk, 2001). Ketentuan lainnya adalah partisipan memiliki dan telah terbiasa menggunakan perangkat komputer jinjing dan tablet (Shin dan Zhu, 2011; Young dkk, 2013).

Kuesioener berisi data demografi (Moras, 2007), lama memiliki perangkat portable, durasi pemakaian /hari, durasi /sekali pemakaian yang mengacu pada penelitian Berolo dkk pada tahun 2011.

Parameter pengukuran ditentukan dari keterkaitan jenis pekerjaan yang diteliti dalam penelitian, yaitu pekerjaan dengan mengunakan komputer. Penggunaan komputer di kalangan mahasiswa akan mengakibatkan bahaya kesehatan, terutama kelelahan otot estremitas atas (OSHA, 1997;Wu dkk, 2009).

Parameter tempat penggunaan komputer portabel digunakan untuk merepresentasikan tempattempat umum yang sering digunakan dalam penggunaan komputer portabel (Kraker, 2009). Parameter aktivitas dalam menggunakan komputer portabel merepresentasikan aktivitas-aktivitas yang 
sering dilakukan saat mengakses komputer portabel dari sisi kegiatan produktif maupun kegiatan hiburan (Berolo dkk, 2011).

Parameter posisi penggunaan komputer portabel dilakukan survei digunakan untuk melihat sejauh mana partisipan beradaptasi untuk menyesuaikan posisi terhadap tempat yang digunakan saat menggunakan komputer portabel (Gold, 2012). Selanjutnya adalah parameter keluhan pada anggota tubuh digunakan untuk mengukur resiko penggunaan komputer portabel terhadap kelelahan otot terhadap posisi penggunaan komputer portabel (Suomalainen dkk, 2010; Berolo, 2011).

Rata-rata usia partisipan dalam penelitian adalah 23,4 tahun. Dengan lama kepemilikan komputer jinjing 3,57 tahun dan 2,27 tahun. Rata-rata partisipan menggunakan komputer jinjing selama 3,79 jam per harinya, sedangkan tablet selama 3,15 jam per harinya. Dalam sekali pemakaian, partisipan menghabiskan waktu selama 2,96 jam dalam menggunakan komputer jinjing, dan 2,52 jam untuk menggunakan tablet. Karakteristik dari responden survei, yaitu usia, jenis kelamin, serta lama kepemilikan komputer portabel yang dijelaskan secara rinci pada penjelasan Tabel 1.

\section{III.1 Perilaku Penggunaan Komputer Portabel di Tempat Umum}

Perilaku penggunaan komputer portabel di tempat umum dapat dilihat pada Gambar 7 dan 8 .

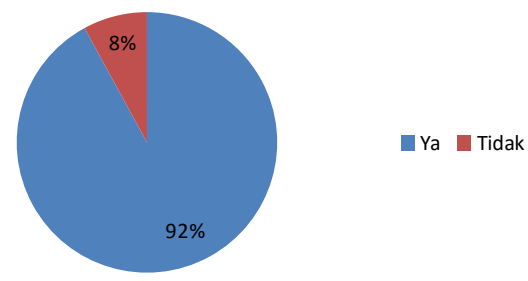

\section{Gambar 7. Penggunaan Tempat Umum Sebagai Tempat Penggunaan Komputer Portabel}

Berdasarkan Gambar 3.1, mayoritas mahasiswa (92\%) menggunakan komputer jinjing dan tablet di tempat-tempat umum.

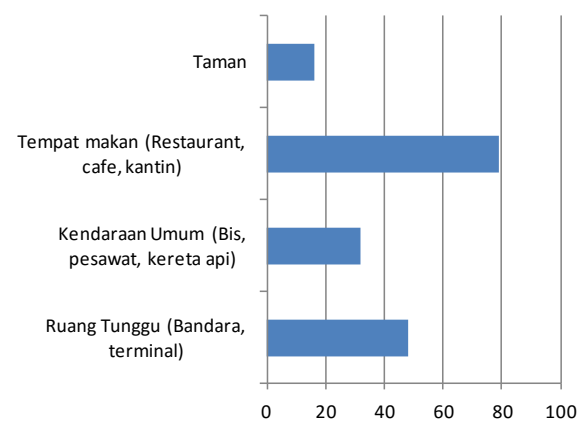

Gambar 8. Karakteristik Penggunaan Tempat Umum

Berdasarkan Gambar 8, sebagian besar mahasiswa (79\%) memilih tempat makan (restaurant, cafe, kantin) sebagai penggunaan komputer jinjing dan tablet. Selanjutnya adalah ruang tunggu (49\%), kendaraan umum (32\%), dan taman (17\%).

\section{III.2 Aktivitas Dalam Menggunakan Komputer Portabel}

Aktivitas dalam penggunaan komputer portabel dapat dilihat pada Gambar 9 dan 10.

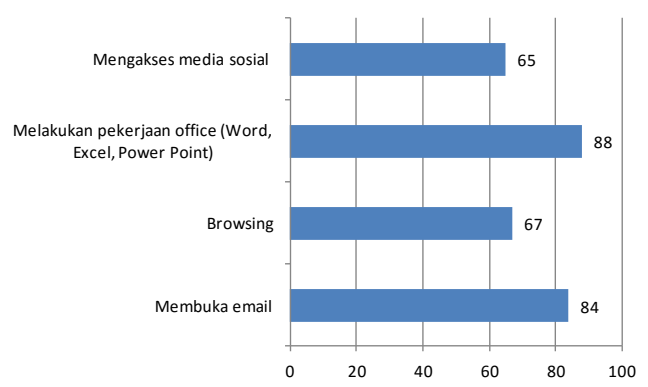

Gambar 9. Aktivitas dengan Menggunakan Komputer Jinjing

Berdasarkan Gambar 9, sebagian besar mahasiswa (88\%) menggunakan komputer jinjing untuk melakukan pekerjaan office (word, excel, power point). Sebanyak $84 \%$ mahasiswa menggunakan komputer portabel untuk membuka surat elektronik. Dilanjutkan dengan kegiatan browsing (67\%) dan mengakses media sosial sebanyak $65 \%$. 


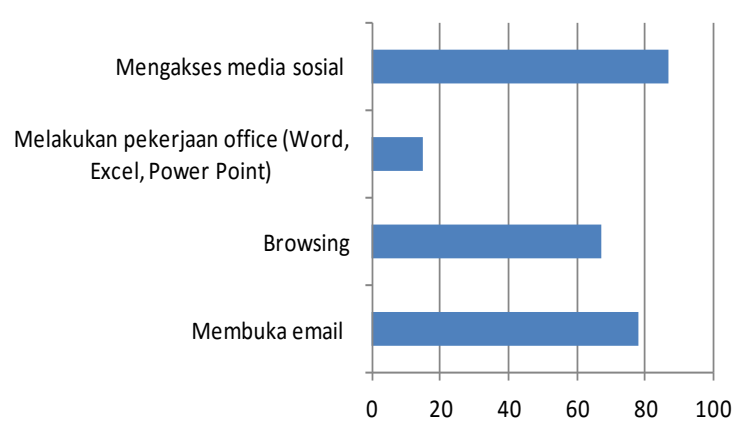

Gambar 10. Aktivitas dengan Menggunakan Tablet

Berbeda dengan penggunaan komputer jinjing, sebagian besar penggunaan tablet dilakukan untuk mengakses media sosial (83\%), dilanjutkan dengan membuka surat elektronik (79\%), kegiatan browsing (64\%), dan pekerjaan pekerjaan office (word, excel, power point) sebanyak $18 \%$.

\section{III.3 Aktivitas Dalam Menggunakan Komputer Portabel}

Posisi penggunaan komputer portable dapat dilihat pada Gambar 11.

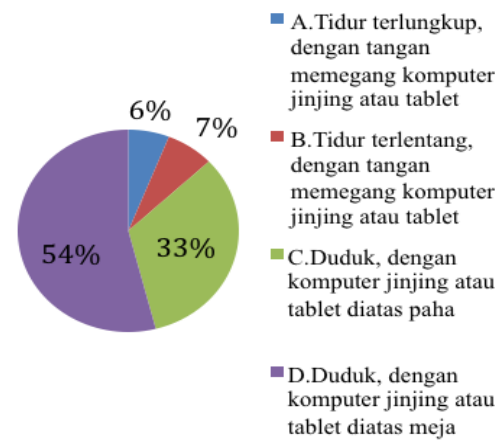

Gambar 11. Posisi Penggunaan Komputer Portabel
Berdasarkan Gambar 11, sebagian mahasiswa (54\%) menggunakan komputer portabel (komputer jinjing dan tablet) dengan posisi duduk dengan komputer portabel di atas meja. Diikuti dengan posisi duduk dengan komputer portabel di atas paha sebesar 33 persen. Posisi yang paling jarang dilakukan oleh partisipan dalam menggunakan portabel komputer adalah tidur terlentang dengan tangan memegang komputer jinjing dan tablet (7\%).

\section{III.4 Keluhan Dalam Penggunaan Komputer Portabel}

Keluhan dalam penggunaan komputer portabel dirasakan pada beberapa area tubuh yang dapat dilihat pada Gambar 12.

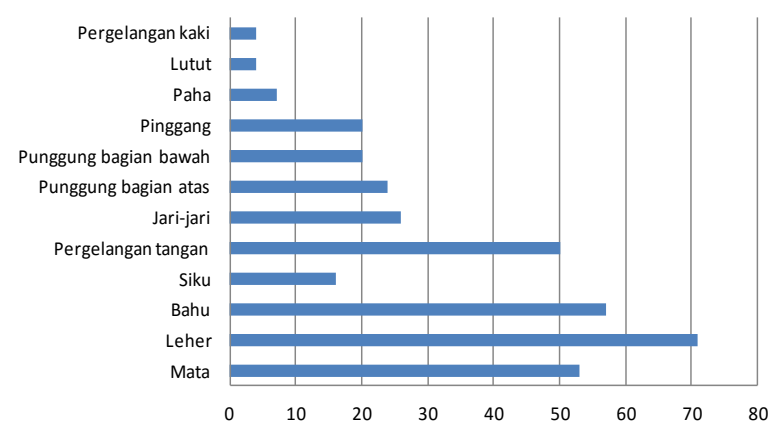

Gambar 12. Area Tubuh yang Mengalami Ketidaknyamanan

Berdasarkan Gambar 12, keluhan tertinggi yang dirasakan mahasiswa dalam menggunakan komputer jinjing dan tablet yaitu bagian leher (71\%). Sedangkan anggota tubuh yang paling jarang mengalami keluhan adalah lutut $(5 \%)$ dan pergelangan kaki (5\%).

Tabel 1. Usia dan Lama Kepemilikan Komputer Portabel

\begin{tabular}{|c|c|c|c|c|c|c|c|}
\hline & \multirow{2}{*}{$\begin{array}{c}\text { Usia } \\
\text { (tahun) }\end{array}$} & \multicolumn{2}{|c|}{$\begin{array}{c}\text { Lama memiliki perangkat } \\
\text { portabel (tahun) }\end{array}$} & \multicolumn{2}{|c|}{$\begin{array}{c}\text { Durasi pemakaian /Hari } \\
\text { (jam) }\end{array}$} & \multicolumn{2}{|c|}{$\begin{array}{c}\text { Durasi /sekali pemakaian } \\
\text { (jam) }\end{array}$} \\
\hline & & $\begin{array}{c}\text { Komputer } \\
\text { jinjing }\end{array}$ & Tablet & $\begin{array}{c}\text { Komputer } \\
\text { jinjing }\end{array}$ & Tablet & $\begin{array}{c}\text { Komputer } \\
\text { jinjing }\end{array}$ & Tablet \\
\hline Rata-rata & 23,400 & 3,570 & 2,270 & 3,790 & 3,150 & 2,960 & 2,520 \\
\hline Stdev & 2,327 & 1,603 & 1,162 & 1,816 & 1,546 & 1,456 & 1,359 \\
\hline
\end{tabular}

Anita Juraida 


\section{IV.Pembahasan}

Hasil penelitian menunjukkan bahwa mahasiswa sering menggunakan komputer portabel (komputer jinjing dan tablet) di tempat-tempat umum. Dari hasil survei yang telah dilakukan, 92 persen mahasiswa menggunakan komputer portabel di tempat-tempat umum.

Penggunaan komputer portabel di tempat umum jauh dari kondisi ideal, sehingga seringkali memaksakan area tubuh sebagai alas, misalnya paha. Dari hasil survei, 33 persen mahasiswa menggunakan bagian tubuh paha sebagai alas untuk menyimpan komputer portabel. Hal ini didukung dengan penelitian Gold dkk (2012) yang menyatakan rentang umur tersebut merepresentasikan mahasiswa tingkat akhir yang sering melaksanakan tugas dengan komputer portabel dengan posisi tanpa menggunakan meja.

Umumnya rentang usia 20-25 tahun merupakan mahasiswa dan professional muda, namun terdapat perbedaan karakteristik pekerjaan serta durasi penggunaan yang dilakukannya. Menurut Cooper dkk (2009), mahasiswa menggunakan komputer lebih lama dibandingkan dengan professional muda, yaitu 35,3 jam per minggu sedangkan professional muda sebesar 33,7 jam per minggu. Mahasiswa menggunakan komputer jinjing untuk mengerjakan tugas dengan menggunakan software, pekerjaan office, serta berkomunikasi melalui jejaring sosial. Sedangkan professional muda lebih banyak menggunakan komputer jinjing untuk pekerjaan office.

Terdapat penelitian yang meneliti hubungan antara penggunaan komputer dengan gangguan otot ekstremitas atas. Menurut Wu dkk (2009) dan Straker dkk (2008), penggunaan bagian komputer, khususnya layar dan keyboard merupakan penyebab terjadinya sikap kerja canggung dan pembebanan statis pada bagian tubuh, seperti leher, bahu, lengan, siku, pergelangan tangan dan tangan serta ditambah gerakan mengetik secara berulang, sehingga meningkatkan risiko gangguan muskuloskeletal ekstremitas atas.

Saat bekerja di tempat non-tradisional, sikap kerja akan terdegradasi menyesuaikan tempat kerja. Menurut Wu dkk (2009) dan Straker dkk (2008), penggunaan bagian komputer, khususnya layar dan keyboard merupakan penyebab terjadinya sikap kerja canggung dan pembebanan statis pada bagian tubuh, seperti leher, bahu, lengan, siku, pergelangan tangan dan tangan serta ditambah gerakan mengetik secara berulang, sehingga meningkatkan risiko gangguan muskuloskeletal ekstremitas atas. Penyesuaian tersebut biasanya tanpa disadari merupakan sikap kerja yang canggung dan statis.

Menurut Bridger (1995), bekerja secara statis menyebabkan otot berkontraksi lebih lama sehingga aliran darah ke jaringan otot terbatas. Hal tersebut menyebabkan kebutuhan oksigen dan pembuangan sisa metabolisme menjadi tidak efektif, serta mempercepat habisnya adenosin trifosfat (ATP) yang menyebabkan kelelahan otot ekstrimitas atas. Hasil penelitian sejalan dengan penelitian Werth dan Reeves (2013); Gold dkk (2012); Young dkk (2012), yang menyatakan potensi risiko meningkat ketika bekerja dengan perangkat komputer portabel dengan sikap kerja yang canggung, khususnya bekerja di tempat kerja non-tradisional.

Durasi penggunaan komputer juga mempengaruhi risiko gangguan otot ekstremitas atas. Penggunaan komputer selama dua sampai empat jam per hari dapat meningkatkan 12 sampai 40 persen risiko nyeri leher dan punggung (Hakala dkk, 2006).

Hasil penelitian menyatakan keluhan tertinggi yang dirasakan mahasiswa dalam menggunakan komputer jinjing dan tablet yaitu bagian leher. Hal tersebut karena adanya penyesuaian anggota tubuh terhadap tempat saat menggunakan komputer portabel. Pernyataan tersebut didukung oleh penelitian dari Gold dkk (2012) yang menyatakan ketinggian layar yang sangat rendah saat menggunakan komputer portabel pada posisi di atas paha menyebabkan leher lebih tertunduk sehingga terjadi peningkatan otot fleksi di sekitar leher. Menurut Werth dan Reeves (2013), seseorang yang mengetik di atas meja, sikap kerjanya akan lebih netral bila dibandingkan dengan orang yang mengetik menggunakan komputer portabel di atas paha. Semakin besar sudut fleksi yang terjadi pada leher akan meningkatkan risiko terjadinya gangguan pada leher Young dkk (2012) karena leher akan terdegradasi saat menggunakan komputer portabel dengan posisi di atas paha.

Pekerjaan menggunakan layar komputer juga rentan terhadap kelelahan mata. Menurut Bali dkk (2007), saat menatap layar komputer, mata berusaha fokus menjaga ketajaman gambar yang dilihatnya yaitu titik-titik kecil (pixel) yang membentuk 
bayangan pada layar monitor. Adanya usaha fokus secara terus menerus mengakibatkan ketegangan yang berulang-ulang pada otot mata dan menurunkan daya akomodasi sehingga menimbulkan kelelahan mata. Hal tersebut merupakan salah satu gangguan penglihatan akibat penggunaan komputer.

Gangguan-gangguan penglihatan yang dialami seseorang dan berkaitan erat dengan pekerjaan menggunakan komputer disebut Computer Vision Syndrome (CVS) (American Optometric Association (AOA), 2012). Gejala yang dirasakan meliputi ketegangan mata, kelelahan mata, iritasi, mata kering, mata terasa panas, mata merah, sakit kepala, penglihatan kabur dan kehilangan fokus.

\section{KeSimpulan dan SARAN}

\section{V.1 Kesimpulan}

Hasil dari penelitian adalah 92\% mahasiswa menggunakan komputer portabel (komputer jinjing dan tablet) di tempat-tempat umum dengan posisi duduk dengan komputer portabel di atas meja. Sebagian besar (79\%) mahasiswa paling banyak menggunakan komputer jinjing dan tablet di tempat makan, diikuti di ruang tunggu (49\%), kendaraan umum $(32 \%)$ dan $\operatorname{taman}(17 \%)$.

Perbedaan yang mendasar dari aktivitas yang dilakukan mahasiswa dengan komputer jinjing adalah untuk pemakaian pekerjaan office (word, excel, power point) sedangkan pada tablet dilakukan untuk mengakses media sosial $(83 \%)$, sedangkan tablet digunakan untuk mengakses media social (83\%).

Interaksi penggunaan komputer portable di tempat umum menyebabkan postur canggung terhadap mahasiswa. Akibatnya mahasiswa mengalami beberapa keluhan ketidaknyamanan di area tubuh, khususnya leher (71\%). Hasil dari penelitian ini dapat memberikan informasi mengenai perilaku mahasiswa dalam menggunakan komputer portable beserta dampak yang ditimbulkannya.

\section{V.2 Saran}

1. Saran untuk penelitian selanjutnya sebaiknya melihat keberagaman jenis komputer portabel beserta ukurannya.

2. Aktivitas dalam penggunaan komputer portabel di kalangan mahasiswa di tiap univerisitas tentunya memiliki keberagaman sendiri. Hal tersebut merupakan tantangan untuk penelitian selanjutnya.

3. Saran untuk penelitian selanjutnya sebaiknya mempertimbangkan perilaku penggunaan komputer portabel dalam rentang usia partisipan lainnya misalnya usia anak-anak dan orang tua.

4. Saran untuk penelitian selanjutnya sebaiknya mempertimbangkan metode pengumpulan kuesioner lainnya.

5. Saran untuk penelitian selanjutnya sebaiknya mempertimbangkan pengaruh-pengaruh yang mungkin akan terjadi pada saat pengumpulan data, misalnya partisipan memiliki riwayat gangguan muskuloskeletal dan penggunaan kacamata pada partisipan.

\section{REFERENSI}

American Optometric Association. (2012). The Effects of Computer Use on Eye Health and Vision. St. Louis : Author

APKOMINDO (2013). Penjualan Tablet 2015 Diperkirakan Capai 21 Juta Unit. Retrivied From APKOMINDO Website:. http://www.apkomindojatim.com/.

Asosiasi Penyelenggara Jasa Internet Indonesia (2012). Profil Pengguna Internet Indonesia 2012. Jakarta

Asundi, K., Odell, D., Luce, A., Dennerlein, T. J. (2011). Changes in Posture Through the Use of Simple Inclines with Notebook Computers Placed on a Standard Desk. Applied Ergonomics, 43, 400- 407.

Bali, J., Navin, N., Thakur, B.R. (2007). Computer Vision Syndrome: A Study of The Knowladge, Attitudes and Practices In Indian Ophtalmoligist. Indian J Ophthalmol, 55, 289-294.

Bridger, R. (1995). Introduction to Ergonomics. NW: CRC Press.

Berolo, S., Wells, R., Amick, B.C. (2011). Musculoskeletal Symptoms Among Mobile Hand-Held Device Users and Their Relationship To Device Use: A Preliminary Study In A Canadian University Population. Applied Ergonomics, 42, 371-378.

Cooper, K.L, Sommerich, C.M., Mirka. G. A .(2009). Collage Students and Computers: Assessment of Usage Patterns and Musculosketal Discomfort. Work. 32 (29).

Dowler, E., Kappes, B., Fenaughty, A., Pemberton, G. (2001). Effects of Neutral Posture on 
Muscle Tension During Computer Use. International Journal Of Occupational Safety And Ergonomics, 7(1), 61-78.

Gold, J.E., Driban, J.B., Thomas, N. (2012). Characterization Of Posture and Comfort In Laptop Users In Non-Desk Settings. Applied Ergonomics, 43, 392-399.

Hakala, P.T., Rimpela, A.H., Saarni, L.A., Salminen, J. J. (2006). Frequent Computer-Related Activities Increase The Risk of NeckShoulder and Low Back Pain In Adolescents. European Journal of Public Health, 16(5), 536-541.

Hamacher, V.C., Zvonko, G., Vranesic, Zaky, S.G. (2001). Computer Organization (5th Edition), McGraw-Hill.

Health Council of the Netherlands. (2012). Computer Use at Work. To the Minister of Social Affairs and Employment, Netherlands.

Kraker, J. (2009). Ergonomic, Subjective Productivity and Comfort of Notebook Computer Users in Computer Trains. Confidential, 151

Moras, J., Gamarra, T.(2007). A Survey of Ergonomics Issues Associated With A University Laptop Program. Scientific Journal of Public Health, 1(2).

OSHA (1997). Working Safely with Video Display Terminals. U.S : Author

Soumalainen, P., Korpinen, L., Paakkonen, R..(2010). A Comparison Of The Usability Of Laptop, Communicator, and Handheld Computer. Journal Of Usability Studies, 111123

Shin, G., Zhu, X. (2011). User Discomfort, Work Posture and Muscle Activity While Using A Touchscreen In A Desktop PC Setting. Ergonomics, 733-44.

Straker, L.M., Coleman, J., Skoss, R., Maslen, B.A. (2008). A Comparison of Posture and Muscle Activity During Tablet Computer, Desktop Computer and Paper Use by Young Children. Ergonomics, 51(4), 540-555.

Werth, A.J., Reeves, K.B. (2013). Assessing Posture While Typing on Portable Computing Devices in Traditional Work Environments and At Home. Human Factors, 1258.

Worksafe. (2010). Guideline for preventing Musculoskeletal Injuries.

Wu, S., Yang, C., Ho, C., Jane, D. (2009). VDT Screen Height and Inclination Effects on Eye and Musculoskeletal Discomfort for Chinese
Wheelchair Users with Spinal Cord Injuries. Industrial Health, 47, 89-93.

Young, J.G., Trudeau, M.B., Odell, D., Marinelli, K., Dennerlein, J.T. (2012). Touch-screen Tablet User Configurations and Case-Supported Tilt Affect Head and Neck Flexion Angles. Work, 41, 81-91.

Young, J.G., Trudeau, M.B., Odell, D., Marinelli, K., Dennerlein, J.T. (2013). Wrist and Shoulder Posture and Muscle Activity During TouchScreen Tablet Use: Effects of Usage Configuration, Tablet Type and Interacting Hand. Work, 45, 59-71.

Zulkarnaen. (2012). Peranan Laptop Support dalam Mengurangi Kelelahan pada Pengguna Laptop. Insan, 14(2). 